Journal of Southeast Asian

\title{
Editor's Introduction to the 10th Anniversary Volume of the Journal of Southeast Asian American Education and Advancement
}

\author{
Wayne E. Wright \\ Purdue University, wewright@purdue.edu \\ Phitsamay S. Uy \\ University of Massachusetts - Lowell, phitsamay_uy@uml.edu \\ Chhany Sak-Humphry \\ University of Hawaii, sak@hawaii.edu
}

Follow this and additional works at: https://docs.lib.purdue.edu/jsaaea

\section{Recommended Citation}

Wright, Wayne E.; Uy, Phitsamay S.; and Sak-Humphry, Chhany (2015) "Editor's Introduction to the 10th Anniversary Volume of the Journal of Southeast Asian American Education and Advancement," Journal of Southeast Asian American Education and Advancement: Vol. 10 : Iss. 1, Article 1.

DOI: $10.7771 / 2153-8999.1119$

Available at: https://docs.lib.purdue.edu/jsaaea/vol10/iss1/1

This document has been made available through Purdue e-Pubs, a service of the Purdue University Libraries. Please contact epubs@purdue.edu for additional information.

This is an Open Access journal. This means that it uses a funding model that does not charge readers or their institutions for access. Readers may freely read, download, copy, distribute, print, search, or link to the full texts of articles. This journal is covered under the CC BY-NC-ND license. 


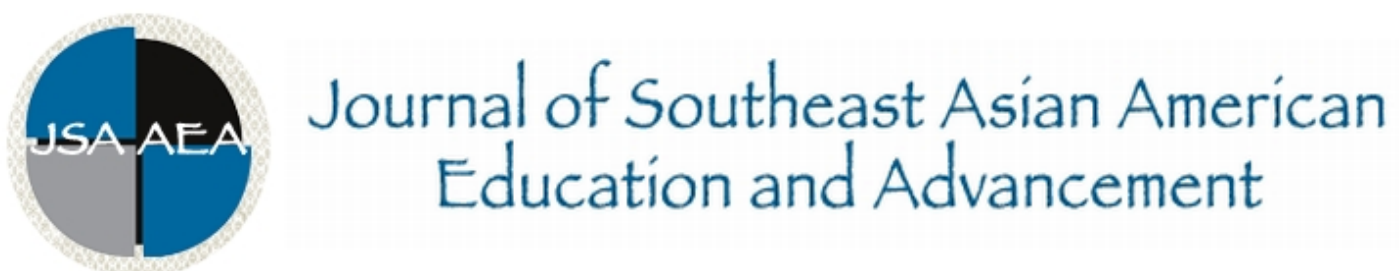

Volume 10 (2015)

\author{
WWW.JSAAEA.org \\ Editors' Introduction to the \\ $1^{\text {th }}$ Anniversary Volume of JSAAEA \\ Wayne E. Wright \\ Purdue University \\ Phitsamay S. Uy \\ University of Massachusetts, Lowell \\ Chhany Sak-Humphry \\ University of Hawaii
}

The Journal of Southeast Asian American Education and Advancement (JSAAEA) began in 2006 as the first online academic peer-reviewed interdisciplinary journal providing a forum for scholars and writers from diverse fields who share a common interest in Southeast Asian (SEA) Americans and communities. With this opening of Volume 10 (2015) of JSAAEA, we celebrate our $10^{\text {th }}$ Anniversary, and along with it some significant and exciting changes for the journal, including a new home, a simpler interface, a beautifully updated design, and additional sources of support. 2015 also is the $40^{\text {th }}$ anniversary of the end of the Vietnam War, the Cambodian and the Laotian Civil Wars, and marks the beginning of the massive exodus of Southeast Asian refugees to the United States.

Before we outline the details of these changes, we feel it is important to review the history, aims and scope of JSAAEA, and reflect back on the growth and impact of the JSAAEA on the field over the past decade.

\title{
Beginnings of JSAAEA
}

The Editor's Introduction to Volume 1 was titled "Fulfilling a Critical Need." For many years, the need for an academic forum where research related to Southeast Asian Americans and communities could be centralized and disseminated to scholars, professionals, leaders, parents, students and other community members was a commonly recurring theme at annual conferences of the National Association

\footnotetext{
@)

SORERISHISFESEREDER Readers are free to copy, display, and distribute this article, as long as the work is attributed to the author(s) and the Journal of Southeast Asian American Education \& Advancement, it is distributed for non-commercial purposes only, and no alteration or transformation is made in the work. More details of this Creative Commons license are available at http://creativecommons.org/licenses/by-nc-nd/3.0/. All other uses must be approved by the author(s) or JSAAEA.

Journal of Southeast Asian American Education \& Advancement, Vol. 10 (2015) ISSN: 2153-8999
} 
Journal of Southeast Asian American Education and Advancement, Vol. 10 [2015], Iss. 1, Art. 1 Wright, Uy \& Sak-Humphry-Editors' Introduction to the 10th Anniversary Volume of JSAAEA

for the Education and Advancement of Cambodian, Laotian, and Vietnamese Americans (NAFEA). As a reminder of the organization's history, the following description appears in the original Editor's Introduction to Volume 1:

First established in 1978 by a group of former Vietnamese educators to provide support to school personnel, social service providers and community-based organizations, the organization was named NAVAE - The National Association of Vietnamese Americans in Education. In 1981, as more refugees from Cambodia and Laos arrived, the group united their efforts with Khmer and Lao educators and community leaders and transformed into a national organization to support educational, social and community development and advancement for all Southeast Asian refugees in their resettlement and acculturation process. Soon after, the organization adopted its current name and has since become an integral partner with many national and state Southeast Asian refugee resettlement organizations, including the Southeast Asian Resource Action Center (SEARAC), local school districts and institutes of higher education, and many mutual assistance associations (MAAs). NAFEA's goals and objectives continue to be inclusive of all Southeast Asian Americans in three primary areas: educational attainment, social/cultural foundations, and community/leadership development.

In 2005, at an Executive Board meeting in Washington, DC, NAFEA decided to address the critical need for a forum to centralize and disseminate quality research by establishing its own online academic journal. The Journal of Southeast Asian American Education and Advancement was born with Executive Board Members Wayne E. Wright serving as Editor, and Chhany Sak-Humphry and KimOanh Nguyen-Lam as Associate Editors. Dr. Nguyen-Lam stepped down after several years of service to JSAAEA when she accepted a new position with the U.S. Department of Education, and was replaced by Phitsamay S. Uy, a long time NAFEA member and JSAAEA board member, and current president of NAFEA. Through NAFEA's sponsorship and the direct involvement of the Executive Board Members serving in key editorial roles, JSAAEA represents the continuous life of the organization, and is the spirit and voice of NAFEA.

JSAAEA was also made possible through generous support provided by the University of Texas at San Antonio (UTSA), Wright's home institution from 2004 to 2014. The College of Education and Human Development and the Department of Bicultural-Bilingual Studies provided server space and technical support for the journal's website, and provided graduate research assistants to serve as editorial assistants and journal managers.

JSAAEA was established with three main goals. The first and most central aim of JSAAEA, as noted above, is to provide a forum for scholars and writers from diverse fields who share a common interest in Southeast Asian Americans and their communities. To accomplish this goal, we invited a number of native Southeast Asian American scholars and other scholars from universities and other educational institutions across the country who actively conduct research within the scope of 
the journal, to serve as Editorial Review Board members. Many of these scholars had attended and presented at past NAFEA conferences. We were gratified to receive overwhelming support, and nearly all who were invited agreed to serve on the board. Many continue to serve on the board today. The participation of these wellrespected scholars gave JSAAEA immediate credibility, and their service providing outstanding feedback to authors via the blind-peer review process. The additional impact of these scholars' active service was twofold; first, it provided opportunities for emerging scholars in the field to be mentored by senior scholars, and second, it ensured the quality of the publications in the journal. JSAAEA would not be possible without the generous time and support of these scholars.

The second goal of JSAAEA is to serve as a vehicle of mentoring and support for Southeast Asian Americans pursuing doctoral degrees in fields relevant to the journal. Thus, we established a separate Doctoral Student Editorial Review Board. Many of these board members have been the strongest contributors to the journal, including publishing their own research, writing book reviews, reviewing submissions, and providing outstanding feedback to the authors through the blind peer-review process. Their involvement with JSSAEA gives these students and emerging scholars valuable experience with and insights into the academic publishing process. Their service to the journal also enables them to add valuable national service to the field on their CVs. Many of our former doctoral student review board members have graduated, secured good jobs at academic institutions, and now serve as members of our Editorial Review Board.

The third goal is to establish JSAAEA as a centralized forum for readers to learn about the growing number of books being published related to Southeast Asian Americans and communities. To be inclusive of our larger SEA community members and move beyond traditional academic work, JSAAEA accepts creative works such as essays, poetry, and other written work by native Southeast Asian Americans. These creative works provide cultural insight into the Southeast Asian American experience in ways that traditional academic research cannot address. The book reviews and creative works sections of JSSAEA were relatively underdeveloped until we were able to recruit two outstanding individuals to serve as editors over these important sections. Vichet Chhuon and Bryan Thao Worra brought tremendous talent as Book Review Editor and as Creative Works Editor respectively, and both sections have flourished under their leadership. Another inclusive strategy that JSAAEA implements is to include Southeast Asian K-12 educators to help review research that connects research and practice.

\section{Accomplishments}

In Volumes 1 - 9, JSAAEA has published over 100 articles, reviews, and creative works. We believe these JSAAEA publications have enriched the fields of education, social services, community development, heritage languages, cultural studies, sociology, Southeast Asian and Asian American Studies, and other diverse academic fields.

JSAAEA operates on a philosophy of open access publishing that is free to view and free for authors to publish. We believe such open access is warranted 
Journal of Southeast Asian American Education and Advancement, Vol. 10 [2015], Iss. 1, Art. 1 Wright, Uy \& Sak-Humphry-Editors' Introduction to the 10th Anniversary Volume of JSAAEA

given that scholars working in public institutions provide much of the research and contributions, and therefore the public should have full access to their work. We felt it important to ensure the JSSAEA publications are not limited to professors and students with access to university libraries, but to all Southeast Asian American community members and leaders and those who work within or have interests in the communities.

Our open-access publishing philosophy has resulted in wide readership of JSAAEA publications. In fact, most publications have over 1,400 downloads; one of our publications has over 16,000 downloads! In contrast, one highly-respected printed academic journal with which we are familiar is held by less than 370 libraries and most articles have been downloaded less than a few hundred times from paid databases. JSAAEA publications have been linked, shared and discussed on social media, are commonly cited in other research publications, and have been used by national and local organizations for advocacy purposes on behalf of Southeast Asian American communities. Some JSAAEA publications have been reprinted-with our permission-in books and other academic outlets.

Publications in JSAAEA have been indexed through the Directory of Open Access Journals (DOAJ) and more recently by EBSCO Host. In addition, JSAAEA's participation in the LOCKSS System has enabled participating libraries to create permanent archives of JSAAEA publications for purposes of preservation and restoration.

JSAAEA has played an important role in supporting the academic careers of many Southeast Asian American scholars and thus has supported the diversification of the academy. For many of our journal's board members and authors, their publications and service to JSAAEA have helped them obtain new jobs, launch new careers, and/or receive favorable annual reviews and promotions to tenured associate and full professors. We also believe that JSAAEA has made an important contribution to helping establish Southeast Asian American Studies as a growing and recognized field of academic study.

\section{Recent Changes}

JSAAEA now has a new home at Purdue University, where lead editor Dr. Wayne E. Wright began a new position in Fall of 2014. Purdue's College of Education and the Department of Curriculum \& Instruction have agreed to provide generous support for JSAAEA. In addition to providing research assistants to serve as editorial assistants/journal managers, JSAAEA now enjoys the full support of Purdue Libraries Scholarly Publishing Services and Purdue University Press. These services include the use of the online publishing platform Digital Commons, powered by BePress, which promises to provide even greater visibility for JSAAEA publications through the use of DOI numbers assigned to each publication, greater indexing capabilities, greater presence in online search engines, and easier integration into social media.

You may have noticed that JSAAEA now has a brand new look featuring a slick design and easy-to-use interface. 
All of JSAAEA's past issues and publications in Volumes 1-9 have been moved to a new server at Purdue. Our dedicated url, www.jsaaea.org, remains the same, but now directs users to the Purdue journal site. Please note that if you are an author of a past publication or have maintained links to specific articles, these links have changed and will need to be updated wherever you have them posted.

Thanks to Purdue's support and shared philosophy, JSAAEA will remain a free-to-publish and free-to-read open access journal. JSAAEA will continue to operate with open volumes, meaning that new articles, reviews, and creative works are added to the current volume as soon as they are ready to be published. This ensures a quicker publication process for accepted articles. JSAAEA will also continue to publish special issues edited by guest editors on important thematic topics.

The scope of JSAAEA also remains the same. However, our original focus on the communities that resulted from Southeast Asian refugee resettlement and immigration from Cambodia, Laos, and Vietnam in the 1980s has expanded over the years to become more inclusive of other Southeast Asian American communities, including recent refugees from Burma such as the Karen and Karenii. Thus, with this $10^{\text {th }}$ Anniversary issue, we are excited to open this volume with an article by Daniel Gilhooly, from the University of Georgia, who documents his experience working to meet the educational and linguistic needs of Karen refugee students in a rural area of Georgia.

\section{Acknowledgements}

There are many individuals whose support have made and continue to make JSAAEA possible. From NAFEA, much appreciation goes to the past and current Executive Board members for their vision and support of JSAAEA, especially those who served at one point or another in various capacities directly with the journal. We thank our current editorial staff and members of our Editorial Review Board and Doctoral Editorial Review board. We also thank the many scholars and writers who have chosen to publish their valuable work in JSAAEA.

At the University of Texas at San Antonio, we wish to thank Dr. Betty Merchant, Dean of the College of Education and Human Development, and Dr. Robert Milk, former Department Chair of the Bicultural-Bilingual Studies who were instrumental in providing the support needed to get JSAAEA started, and to current department chair Dr. Belinda Flores who was equally supportive. We are indebted to the IT department in the college for the technical expertise, in particular Jorge Garza who completed the initial installation of the Open Journal Systems (OJS) software on a dedicated server and provided several years of support, and subsequently to William Ingram and Michael Brock who continued to maintain and update the servers and software, and troubleshoot technical problems. Michael was also instrumental in supporting the journal during the transition period. Several outstanding former graduate students at UTSA served as editorial assistants and journal managers of JSAAEA, including James Knaack, Dr. Shereen Bhalla, Mariana Kuhl, Kathleen Langham, Dr. Sovicheth Boun, and most recently Matthew Kraft and (soon to be Dr.) Yeng Yang. 
At Purdue University, we are most grateful to College of Education Dean, Dr. Maryann Santos de Barona, Associate Dean James Lehman, and Department of Curriculum \& Instruction Head, Dr. Phil VanFossen. We especially thank Marshall Klassen, our new graduate assistant Journal Manager, who has had the monumental task of keeping the journal going during the transition and facilitating the transition process. At Purdue University Press, we express our deep gratitude to Interim CoDirector, Katherine Purple, and especially to David Scherer, Scholarly Repository Specialist, for his many hours of work on all aspects of the transition of the journal to Purdue. We also express our appreciation to the staff at BePress for the beautiful re-design of the journal's look and other support services.

\section{Into the Future}

We want to acknowledge all of our current and past board members, authors, and readers of JSAAEA and hope you'll continue to enjoy the journal with its new look in its new home. We look forward to the next 10 years, and invite all readers to help spread the word of JSAAEA on social media and promote the journal among your colleagues and friends. We would love to publish an even greater volume of high quality research, reviews and creative works that contribute to building the field and knowledge base of Southeast Asian American Education and Advancement. 


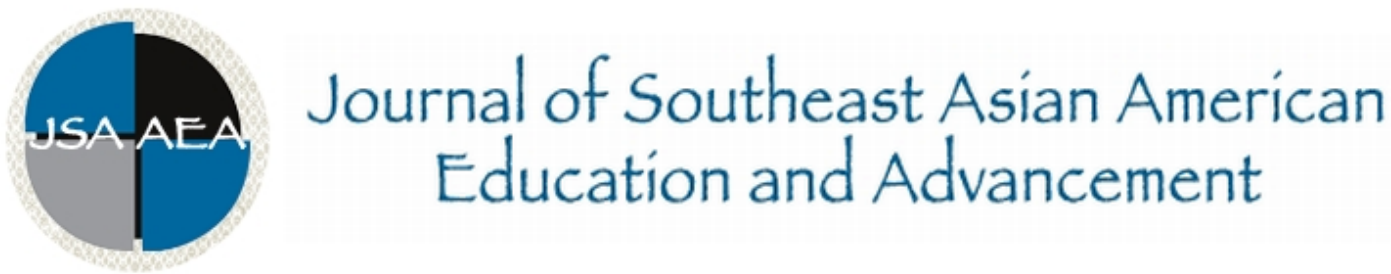

Volume 10 (2015)

WWW.JSAAEA.org

\title{
Editor
}

Dr. Wayne E. Wright

Purdue University

\author{
Associate Editors \\ Dr. Chhany Sak-Humphry \\ University of Hawaii at Manoa \\ Dr. Phitsamay Sychitkokhong Uy \\ University of Massachusetts, Lowell
}

\section{Book Review Editor}

Dr. Vichet Chhuon

University of Minnesota

\section{Creative Works Editor \\ Bryan Thao Worra \\ Lao Assistance Center}

\section{Journal Manager \\ Marshall Klassen \\ Purdue University}

\section{Editorial Review Board}

Dr. Steve Arounsack

California State University, Stanislaus

Dr. Sovicheth Boun

State University of New York at Fredonia

Dr. George Chigas

University of Massachusetts, Lowell

Dr. Hien Duc Do

San Jose State University

Dr. Sophal Ear

U.S. Naval Postgraduate School
Dr. Carl L. Bankston III

Tulane University

Dr. Phala Chea

Lowell Public Schools

Dr. Loan Dao

University of Massachusetts, Boston

Dr. Changming Duan

University of Missouri, Kansas City

Dr. Sothy Eng

Lehigh University 


\author{
Dr. Jeremy Hein \\ University of Wisconsin, Eau Claire \\ Dr. Nancy H. Hornberger \\ University of Pennsylvania \\ Dr. Peter Nien-Chu Kiang \\ University of Massachusetts, Boston \\ Dr. Kevin K. Kumashiro \\ University of Illinois, Chicago \\ Dr. Ravy Lao \\ California State University, Los Angeles \\ Dr. Stacey Lee \\ University of Wisconsin, Madison \\ Dr. Sue Needham \\ California State University, Dominguez Hills \\ Dr. Max Niedzwiecki \\ Daylight Consulting Group \\ Dr. Clara Park \\ California State University, Northridge \\ Dr. Mark Pfeifer \\ SUNY Institute of Technology \\ Dr. Loan T. Phan \\ University of New Hampshire \\ Dr. Karen Quintiliani \\ California State University, Long Beach \\ Dr. Angela Reyes \\ Hunter College, The City University of New York \\ Dr. Fay Shin \\ California State University, Long Beach \\ Dr. Cathy J. Schlund-Vials \\ University of Connecticut, Storrs \\ Dr. Yer J. Thao \\ Portland State University \\ Dr. Myluong Tran \\ San Diego State University \\ Dr. Monica M. Trieu \\ Purdue University \\ Dr. Silvy Un \\ Frost Lake Elementary School \\ Dr. Terrence G. Wiley \\ Center for Applied Linguistics \\ Dr. Zha Blong Xiong \\ University of Minnesota
}

Dr. Vincent K. Her

University of Wisconsin, Eau Claire

Dr. Samlong Inthaly

Minneapolis Public Schools

Dr. Ketmani Kouanchao

Mt. San Jacinto College

Dr. Ha Lam

Arizona State University

Dr. Jonathan H. X. Lee

San Francisco State University

Dr. Monirith Ly

Royal University of Phnom Penh

Dr. Bic Ngo

University of Minnesota

Dr. Leakhena Nou

California State University, Long Beach

Dr. Isabelle Thuy Pelaud

San Francisco State University

Dr. Giang Pham

University of Massachusetts

Dr. Bounlieng Phommasouvanh

Minnesota Department of Education

Dr. Kalyani Rai

University of Wisconsin, Milwaukee

Dr. Soveacha Ros

Royal University of Phnom Penh

Dr. Nancy J. Smith-Hefner

Boston University

Dr. Christine Su

Ohio University

Dr. Loan Tran

University of California, Riverside

Dr. Tinou Tran

Alief Independent School District

Dr. Khatharya Um

University of California, Berkeley

Dr. Linda Trinh Vo

University of California, Irvine

Dr. Yang Sao Xiong

University of Wisconsin-Madison

Dr. Kou Yang

California State University, Stanislaus 


\section{Doctoral Student Editorial Review Board}

\section{Virak Chan}

University of Texas at San Antonio

Annie BichLoan Duong

San Joaquin County Office of Education

Minh Mai

University of Wisconsin-Madison

Hoa Nha Nguyen

Boston College

Malaphone Phommasa

University of California, Santa Barbara

Krissyvan Truong

Claremont Graduate University

Soua Xiong

San Diego State University \& Claremont

Graduate University
Keo Chea-Young

University of Pennsylvania

Peter Tan Keo

Columbia University

Dung Minh Mao

University of Minnesota

Thien-Huong Ninh

University of Southern California

Alisia Tran

University of Minnesota

Molly Wiebie

The University of Texas at Austin

Anna H. Yang

University of Georgia

Lesley Yang

University of Minnesota 